\title{
Variasi Volume Gliserol terhadap Sifat Fisis Plastik Biodegradable Berbahan Dasar Pati Ubi Kayu (Manihot Esculenta Cranz)
}

\author{
Marsi D. S. Bani \\ Program Studi Pendidikan Fisika, Universitas Nusa Cendana, Kupang, NTT \\ Jl. Adisucipto, Penfui Kupang, NTT, 85111, Indonesia \\ E-mail: marsibanispd07@yahoo.co.id
}

Article History:

Received: dd-mm-yyyy; Received in revised form: dd-mm-yyyy; Accepted: dd-mm-yyyy;

Available online: dd-mm-yyyy

\begin{abstract}
The use of starch as the main ingredient in making plastic has great potential especially in Indonesia with various starch-producing plants. To obtain bioplastics, starch is added with glycerol plasticizer, so that the plastic is more flexible and elastic. In this study, cassava starch (Manihot esculenta cranz) was used and the volume of glycerol as plasticizer was varied by $2 \mathrm{ml}, 3 \mathrm{ml}$ and $4 \mathrm{ml}$. The aim to be achieved in this study was to determine the volume variation of glycerol against the tensile strength of environmentally friendly biodegradable plastic films made from cassava starch. In addition, to find out what is the density of environmentally friendly biodegradable plastic films made from cassava starch. Cassava starch was obtained by isolating cassava starch 15 grams and then mixed with $2 \mathrm{ml}$ glycerol (varied $3 \mathrm{ml}$ and $4 \mathrm{ml}$ ) and $50 \mathrm{ml}$ of aquades then heated while stirring with magnetic stirrer to form a thick dough. The mixture is then printed on a stainless steel mold. The results obtained in the form of thin sheets of plastic film that has been tested for tensile strength and density. After that followed by morphological analysis. The results of the biodegradable plastic characterization for tensile strength of plastic films with volume variations of glycerol $2 \mathrm{ml}, 3 \mathrm{ml}$ and $4 \mathrm{ml}$ respectively as follows: $0.001 \mathrm{Mpa} 0.069 \mathrm{Mpa} 0.005$ Mpa. For the density of biodegradable plastics for variations in volume of glycerol $2 \mathrm{ml}, 3 \mathrm{ml}$ and $4 \mathrm{ml}$ respectively $0.0009 \mathrm{~g} / \mathrm{mm}^{3}, 0.0015 \mathrm{~g} / \mathrm{mm}^{3}$ and $0.0014 \mathrm{~g} / \mathrm{mm}^{3}$.
\end{abstract}

Keywords: Cassava Stracth; Gliserol; Plastik Biodegradable.

\begin{abstract}
Abstrak
Penggunaan pati sebagai bahan utama pembuatan plastik memiliki potensi yang besar terlebih lagi di Indonesia terdapat berbagai tanaman penghasil pati. Untuk memperoleh bioplastik, pati ditambahkan dengan plastisizer gliserol, sehingga diperoleh plastik yang lebih fleksible dan elastis. Pada penelitian ini digunakan pati ubi kayu (Manihot esculenta cranz) dan volume gliserol sebagai plastisizer divariasikan sebanyak $2 \mathrm{ml}, 3 \mathrm{ml}$ dan $4 \mathrm{ml}$. Tujuan yang ingin dicapai dalam penelitian ini adalah untuk mengetahui variasi volume Gliserol terhadap kuat tarik film plastik biodegradable ramah lingkungan berbahan dasar pati ubi kayu. Selain itu untuk mengetahui berapa densitas film plastik biodegradable ramah lingkungan berbahan dasar pati ubi kayu. Pati ubi kayu diperoleh dengan mengisolasi pati ubi kayu 15 gram kemudian dicampurkan dengan $2 \mathrm{ml}$ gliserol (divariasikan $3 \mathrm{ml}$ dan $4 \mathrm{ml}$ ) dan $50 \mathrm{ml}$ aquades kemudian dipanaskan sambil diaduk dengan magnetik stirerr hingga berbentuk adonan yang kental. Campuran tersebut kemudian dicetak pada cetakan stainless steel. Hasil yang diperoleh berupa lembaran tipis film plastik yang telah diuji kekuatan tarik
\end{abstract}


dan densitasnya. Setelah itu dilanjutkan dengan analisa morfologi. Hasil karakterisasi plastik biodegradable untuk kuat tarik film plastik dengan variasi volume gliserol $2 \mathrm{ml}, 3 \mathrm{ml}$ dan 4 $\mathrm{ml}$ berturut-turut sebagai berikut: 0.001 Mpa 0,069 Mpa 0.005 Mpa. Untuk densitas dari plastik biodegradable untuk variasi volume gliserol $2 \mathrm{ml}, 3 \mathrm{ml}$ dan $4 \mathrm{ml}$ berturut-turut adalah $0.0009 \mathrm{~g} / \mathrm{mm}^{3}, 0.0015 \mathrm{~g} / \mathrm{mm}^{3}$ dan $0.0014 \mathrm{~g} / \mathrm{mm}^{3}$.

Kata Kunci: Pati Ubi Kayu; Gliserol; Plastik Biodegradable.

\section{Pendahuluan}

Kemajuan ilmu pengetahuan dan teknologi membantu manusia untuk meningkatkan kesejahteraan dan kemakmuran hidupnya. Banyak produk yang dapat dihasilkan seiring meningkatnya kemajuan ilmu pengetahuan dan teknologi. Salah satu diantaranya adalah plastik yang begitu akrab dengan kehidupan manusia. Plastik merupakan produk teknologi yang erat dengan kehidupan. Plastik banyak digunakan untuk berbagai hal diantaranya sebagai pembungkus makanan, alas makan dan minum, untuk keperluan sekolah, kantor, automotif, dan berbagai sektor lainnya, karena memiliki banyak keunggulan antara lain: fleksibel, ekonomis, transparan, kuat, tidak mudah pecah, bentuk laminasi yang dapat dikombinasikan dengan berbagai kemasan lain dan sebagian ada yang tahan panas dan stabil ${ }^{1}$. Selain itu plastik juga lebih ringan dibandingkan dengan logam dan gelas. Bahan ini bisa dibentuk lembaran sehingga dapat dibuat kantong atau dibuat kaku sehingga bisa dibentuk sesuai desain dan ukuran yang diinginkan.

Disamping memiliki kelebihan tersebut penggunaan plastik sebagai pengemas makanan menghadapi berbagai persoalan lingkungan, yaitu tidak dapat didaur ulang dan tidak dapat diuraikan secara alami oleh mikroba di dalam tanah, sehingga terjadi penumpukan sampah plastik yang menyebabkan pencemaran dan kerusakan bagi lingkungan. Hal ini disebabkan plastik sintetik mempunyai kestabilan fisiko-kimia yang terlalu kuat sehingga plastik sangat sukar terdegradasi (teruraikan) secara alami dan telah menimbulkan masalah dalam penanganan limbahnya.

Sampah plastik rata-rata memiliki porsi sekitar $10 \%$ dari total volume sampah. Dari jumlah itu, sangat sedikit yang dapat didaur ulang. Padahal, sampah plastik berbahan polimer sintetik tidak mudah diurai organisme dekomposer. Butuh 300 - 500 tahun agar bisa terdekomposisi atau terurai sempurna. Membakar plastik pun bukan pilihan baik. Plastik yang tidak sempurna terbakar di bawah suhu $800^{\circ} \mathrm{C}$, akan membentuk dioksin. Senyawa

1 Elisa Julianti and Mimi Nurminah, Teknologi Pengemasan: Buku Ajar (Medan: Fakultas Pertanian Universitas Sumatera Utara, 2006). 
inilah yang berbahaya ${ }^{2}$. Plastik konvensional yang dibakar akan meleleh dan memadat kembali. Bahan plastik memiliki sifat perintang yang tinggi terhadap permeabilitas $\mathrm{O}_{2}$ dan $\mathrm{CO}_{2}$. Oleh karena itu kegiatan menimbun sampah plastik secara tidak langsung akan mengganggu sirkulasi udara yang ada di dalam tanah.

Selain itu juga terdapat kelemahan lain diantaranya adalah bahan baku utama pembuatan plastik yang berasal dari minyak bumi, yang keberadaannya semakin menipis dan tidak dapat diperbaharui. Kelemahan plastik lain yang berbahaya bagi kesehatan manusia adalah migrasi residu monomer vinil klorida sebagai inti penyusun polivinilclorida (PVC) yang bersifat karsinogenik monomer-monomer tersebut akan masuk ke dalam makanan dan selanjutnya akan masuk ke dalam tubuh orang yang mengkonsumsinya. Penumpukan bahan kimia yang telah masuk kedalam tubuh ini tidak akan larut dalam air sehingga tak dapat dikeluarkan bersama feses atau urin. Penumpukan bahan-bahan seperti ini yang bisa menimbulkan gangguan kesehatan bagi pemakaiannya dan bisa mengakibatkan kanker ${ }^{3}$. Jadi, diperlukan usaha lain untuk mengatasi sampah plastik yaitu dengan membuat plastik yang dapat terurai secara biologis atau disebut dengan plastik biodegradable ${ }^{4}$.

Perlu adanya inovasi dalam pembuatan plastik yang ramah lingkungan. Ada lima syarat yang dibutuhkan kemasan yaitu penampilan, perlindungan, fungsi, bahan dan biaya, serta penanganan limbah kemasan ${ }^{5}$. Dengan adanya persyaratan bahwa kemasan yang digunakan harus ramah lingkungan, maka solusi yang tepat adalah dengan membuat plastik biodegradable ramah lingkungan.

Plastik biodegradable yaitu plastik yang dapat teruraikan (terdegradasi) secara alami oleh alam dan terbuat dari sumber yang dapat diperbaharui salah satunya adalah pati. Tepung atau pati merupakan jenis polimer terkenal yang secara alami diproduksi oleh tumbuhan jenis umbiumbian, jagung dan beras (umumnya pati terdapat pada tanaman yang mengandung banyak karbohidrat) dalam bentuk butiran halus. Butiran halus dari pati berbeda untuk masing-masing jenis tanaman tetapi tetap memiliki komposisi umum terdiri dari dua fraksi yang dapat dipisahkan

2 Vedder Taylor, Edible Film (London: CRC Press, 2008).

3 Siswono, Jaringan Informasi Pangan Dan Gizi, vol. XIV (Jakarta: Ditjen Bina Gizi Masyarakat, 2008).

${ }^{4}$ Yuli Darni, A. Chici, and S. D. Ismiyati, "Sintesa Bioplastik Dari Pati Pisang Dan Gelatin Dengan Plasticizer Gliserol," in Dalam Seminar Nasional Sains Dan Teknologi II, 2008.

5 Rizal Syarief, Sassya Santausa, and S. T. Isyana, "Teknologi Pengemasan Pangan," Laboratorium Rekayasa Proses Pangan, PAU Pangan Dan Gizi, IPB, 1989. 
dengan air panas. Fraksi terlarut dalam amilosa (10-20\%) dan fraksi tidak terlarut amilopektin (80-90\%) ${ }^{6}$.

Berdasarkan fakta dan kajian ilmiah yang ada, maka pati merupakan polisakarida paling melimpah kedua. Fungsi pati dalam tumbuhan sebagai cadangan makanan, juga sebagai cadangan makanan, juga sebagai substrat untuk produksi amilase. Pati terdapat dalam gandum, beras, jagung, kentang, jenis umbi-umbian?

Hasil pertanian di Indonesia yang sangat potensial untuk dikembangkan menjadi biopolimer adalah jagung, sagu, kacang, kedele, tepung tapioka, ubi kayu (nabati) dan kitin dari kulit udang ${ }^{8}$. Bahan dasar yang dipilih dalam pembuatan plastik biodegradable ini adalah ubi kayu. Ubi kayu di Indonesia masih digolongkan sebagai hasil pertanian sekunder, karena sebagai makanan pokok, Indonesia masih sebagian besar mengutamakan beras. Walaupun sebagai hasil pertanian sekunder, tetapi produksi ubi kayu lebih tinggi apabila dibandingkan dengan jagung dan ubi jalar.

Secara fisik ubi kayu dapat berbentuk silinder, kerucut atau oval. Panjangnya berkisar 15-100 cm. Setiap 100 gram ubi kayu mengandung 62,5 g air, 34,7 g karbohidrat, 1,2 g protein dan 0.3 g lemak. Kandungan karbohiratnya lebih tinggi dibandingkan dengan ubi jalar 27,9\%. Selain kandungan pati yang tinggi potensi ubi kayu di Nusa Tenggara Timur sangat besar dan pemanfaatannya yang juga belum maksimal, yakni kebanyakan untuk makanan sekunder (pendamping nasi dan jagung) dan pakan ternak dan sebagian untuk industri kuliner.

Pati ubi kayu sering digunakan sebagai bahan tambahan dalam industri makanan dan industri yang berbasis pati karena memilki kandungan pati yang cukup tinggi ${ }^{9}$ Kandungan pati pada beberapa bahan pangan disajikan pada Tabel.1

${ }^{6}$ Ralph J. Fessenden and Joan S. Fessenden, Organic Chemistry, 6 edition (Place of publication not identified: Cengage Learning, 1998).

7 Darni, Chici, and Ismiyati, "Sintesa Bioplastik Dari Pati Pisang Dan Gelatin Dengan Plasticizer Gliserol."

8 Feris Firdaus and Chairil Anwar, "Potensi Limbah Padat-Cair Industri Tepung Tapioka Sebagai Bahan Baku Film Plastik Biodegradabel," Jurnal Logika 1, no. 2 (2004).

${ }^{9}$ Maulana Karnawidjaja Wahyu, "Pemanfaatan Pati Singkong Sebagai Bahan Baku Edible Film," Beswan Djarum. Fakultas Teknologi Industri Pertanian. Universitas Padjadjaran. Bandung, 2009. 
Tabel.1 Kandungan Pati pada Beberapa Bahan Pangan

\begin{tabular}{cc}
\hline Bahan Pangan & Pati (\% dalam \\
\hline Biji gandum & 67 \\
Beras & 89 \\
Jagung & 57 \\
Biji sorghum & 72 \\
Kentang & 75 \\
Ubi jalar & 90 \\
Ubi kayu & 90 \\
\hline Sumber: Liu (2005) dalam Cui (2005) &
\end{tabular}

Menurut data Peta Ketahanan dan Kerentanan Pangan Nusa Tenggara Timur (NTT) 2010, produksi tanaman ubi kayu di NTT pada tahun 2009 sebesar 913.053 ton. Melihat kandungan pati pada ubi kayu sebesar 90\%, maka pada tahun tersebut dapat menghasilkan $821.747,7$ ton pati ubi kayu. Produksi pati yang tinggi, penanamannya yang mudah, dan mudah didapatkan di Indonesia menjadikan ubi kayu sangat potensial dijadikan sebagai bahan dasar plastik biodegradable.

Plastik berbahan dasar pati aman bagi lingkungan sebagai perbandingan, plastik tradisional membutuhkan waktu sekitar 50 tahun agar dapat terdekomposisi secara alamiah, sementara plastik biodegradable dapat terkdekomposisi 10 hingga 20 kali lebih cepat. Bioplastik atau plastik biodegradable dapat terdegradasi (teruraikan) secara alamiah adalah plastik atau polimer yang secara alamiah dapat dengan mudah terdegradasi baik melalui serangan mikroorganisme maupun oleh cuaca (kelembaban dan radiasi sinar matahari) menjadi air $\left(\mathrm{H}_{2} \mathrm{O}\right)$, karbondioksida $\left(\mathrm{CO}_{2}\right)$ dan senyawa organik yang tentunya tidak mencemari lingkungan.

Plastik berbahan dasar pati memiliki dua kekurangan yaitu rendahnya kekuatan mekanik serta bersifat hidrofilik. Yang dimaksud dengan rendahnya kekuatan mekanik yaitu plastik yang dihasilkan mudah rapuh sehingga tidak mampu menahan beban yang berat. Hidrofilik berasal dari dua kata yaitu hidro yang berarti air dan filik yang berarti suka. Hidrofilik adalah zat yang dapat larut di dalam air. Apabila plastik yang dihasilkan bersifat hidrofilik maka plastik tidak dapat digunakan untuk mengisi bahan dalam bentuk cairan.

Untuk mengatasi kekurangan plastik berbahan dasar pati tadi maka ada beberapa cara yang dapat dilakukan, salah satunya adalah pencampuran pati dengan polimer sintetis atau polimer lain seperti polipropilen. Namun hasilnya hanya pati saja yang dapat terdegradasi, polimer sintetis yang digunakan sebagai campuran tetap sulit terdegradasi sehingga masih menimbulkan masalah lingkungan. Selanjutnya cara lain adalah

\footnotetext{
${ }^{10}$ Wahyu.
} 
pencampuran pati dengan selulosa, gelatin dan jenis biopolimer lainnya yang dapat memperbaiki kekurangan dari sifat plastik berbahan pati.

Kualitas plastik biodegradable dapat dilihat dari sifat mekaniknya yang dipengaruhi oleh beberapa faktor yaitu konsentrasi padatan terlarut dalam larutan film, suhu, penambahan pemplastis, dan jenis polimer ${ }^{11}$. Pemplastis yang digunakan adalah gliserol. Gliserol bersifat fleksibel dan mengurangi kekakuan. Dalam variasi yang pas maka plastik biodegradable dapat digunakan sebagai plastik kemasan yang konvensional dengan keunggulan yang sama namun akan hancur dan terurai oleh aktivitas mikroorganisme menjadi air dan karbondioksida.

\section{Metode}

Penelitian ini dilakukan pada bulan april 2016 sampai selesai di Laboratorium Pendidikan Kimia Fakultas Keguruan dan Ilmu Pendidikan (FKIP) Universitas Nusa Cendana (UNDANA). Pembuatan sampel film plastik dari pati ubi kayu dilakukan di Laboratorium pendidikan Kimia FKIP UNDANA pada bulan april-mei 2018, Penelitian tentang pembuatan dan karakterisasi sampel film plastik dari pati ubi kayu (uji tarik) dilakukan di Laboratorium material jurusan Fisika Fakultas MIPA Universitas Brawijaya Malang pada bulan mei 2018 dan pengukuran densitas dilakukan di Laboratrium Pendidikan Kimia FKIP UNDANA pada bulan mei 2018, sedangkan proses scanning electron microscope (SEM) dilakukan di Laboraturium Bioscience Universitas Brawijaya Malang pada bulan Mei-Juni 2018.

\section{Bahan dan Alat}

Bahan-bahan yang digunakan dalam pembuatan sampel film plastik antara lain pati ubi kayu, , gliserol, asam asetat 1\%, $\mathrm{NaOH} \mathrm{1 \%} \mathrm{dan} \mathrm{aquades.}$ Ubi kayu untuk pembuatan pati diperoleh dari daerah Kecamatan Amanuban Tengah, Kabupaten Timor Tengah Selatan. Asam asetat asetat, gliserol 85\% dan aquades diperoleh di Laboraturim Kimia Undana.

Alat-alat yang digunakan ketika dalam pembuatan pati ubi kayu antara lain pisau, blender, toples, sendok dan baki. Peralatan yang digunakan ketika pembuatan sampel film plastik di Laboraturium Pendidikan Kimia Undana meliputi loyang cetakan, oven, gelas ukur, gelas kimia, pengaduk, termometer, pipet, dan magnetic stirrer. Alat yang digunakan ketika karakterisasi antara lain yaitu tensile tester dan micrometer secrup dan seperangkat alat SEM.

11 Vemy Suryo Qushayyi, “Desain Teknologi Pembuatan Plastik Biodegradable Dari Pati Sagu Dengan Pemanfaatan Fermentasi Asam Laktat (Kajian Penambahan Kitosan Dan Gelatin)" (Sarjana, Universitas Brawijaya, 2014), http://repository.ub.ac.id/149882/. 


\section{Variasi Volume Gliserol...}

\section{Prosedur Pelaksanaan Penelitian}

1. Tahap Persiapan

Serangkaian kegiatan pelaksanaan penelitian dapat dilihat pada Gambar.1 Prosedur pelaksaan penelitian yang pertama adalah menyiapkan semua alat dan bahan yang dibutuhkan dalam penelitian. Bahan larutan yang harus dipersiapkan yaitu larutan pati ubi kayu dan gliserol. Sebelum membuat larutan pati ubi kayu, maka harus membuat pati ubi kayu terlebih dahulu. Proses yang kedua yaitu pencampuran semua bahan kemudian pemanasan menggunakan magnetic stirrer pada suhu $52^{\circ} \mathrm{C}-64^{\circ} \mathrm{C}$ dengan kecepatan putar $400 \mathrm{rpm}$. Proses selanjutnya yaitu pencetakan ke loyang dan pengeringan menggunakan oven dengan suhu $45^{\circ} \mathrm{C}$, kemudian pendinginan pada suhu kamar selama 6 jam. Langkah terakhir yaitu karakterisasi sampel film plastik kemudian analisis hasil dan pembahasan serta diakhiri dengan penulisan laporan. Seperti tampak pada gambar.1.

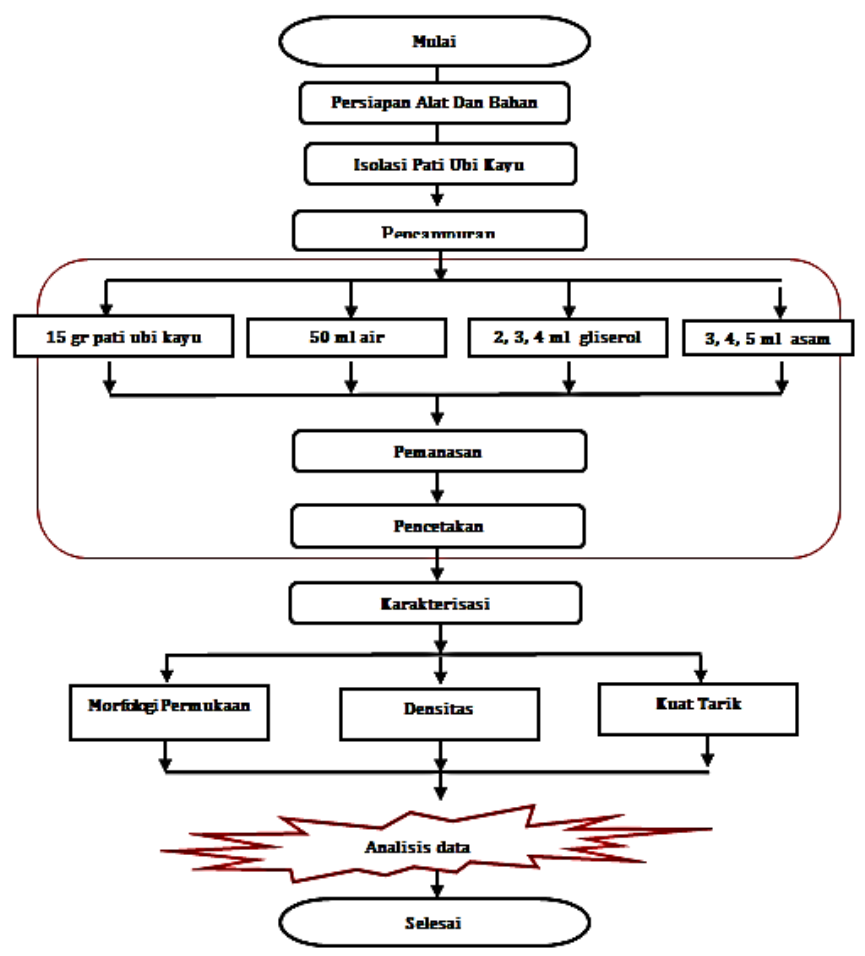

Gambar.1 Diagram Alur Penelitian 


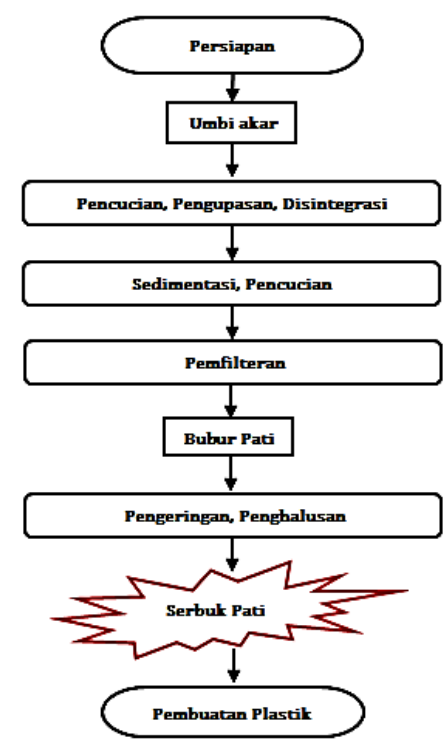

Gambar.2. Diagram Isolasi Pati Ubi Kayu

2. Uji Morfologi Permukaan Film Plastik

Uji morfologi permukaan film plastik dilakukan untuk mengetahui sifat struktur mikro film plastik yang telah dibuat. Dalam hal ini dilihat permukaan dan homogenitas film plastik yang terdiri dari pencampuran pati ubi kayu. Sebelum diuji menggunakan SEM, sampel terlebih dahulu dipotong kecil dengan ukuran $1 \mathrm{~cm} \times 1 \mathrm{~cm}$. Sampel yang sudah dipotong tersebut kemudian permukaannya dilapisi platina disebut juga proses coating dengan menggunakan alat sputter coater. Tujuannya adalah untuk memberikan sifat konduktor pada sampel. Pengujian sampel dilakukan dengan menggunakan SEM pada kondisi perbesaran 1000x serta operasi tegangan $15 \mathrm{kV}$ dan $20 \mathrm{kV}$.

3. Uji Densitas Film Plastik

Kerapatan ini diukur dengan menggunakan alat sederhana, yaitu timbangan digital, micrometer secrup, gunting dan penggaris. Pengukuran kerapatan ini dimulai dengan memotong beberapa sampel dengan ukuran seragam masing- masing dengan panjang $2 \mathrm{~cm}$ dan lebar $1 \mathrm{~cm}$. Kemudian menimbang potongan sampel tersebut dengan menggunakan timbangan digital. Potongan sampel juga diukur tinggi atau tebalnya dengan menggunakan micrometer secrup, kemudian melakukan perhitungan volume dari potongan. Penentuan uji persentasi ketahanan air film plastik dilakukan dengan membandingkan massa film plastik dengan volume film plastik.

4. Uji Kuat Tarik

Proses pengujian kekuatan tarik dilakukan dengan stress and strain aparatus. Pengujian dilakukan dengan memotong sampel Film plastik sesuai dengan standar ISO 527-3:1995 seperti ditunjukkan pada Gambar.3. 


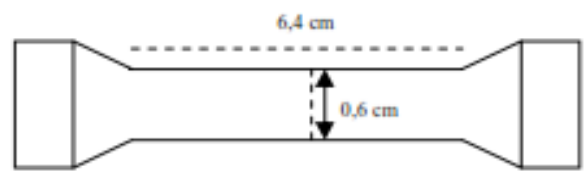

Gambar.3 Bentuk Spesimen Uji Kekuatan Tarik

Kemudian ujung sampel dijepit mesin penguji tensile.selanjutnya dilakukan pencatatan ketebalan dan panjang awal sampel. Tombol startpada komputer ditekan kemudian alat akan menarik sampel dengan kecepatan 100 $\mathrm{mm} /$ menit sampai sampel putus. Nilai kekuatan tarik didapatkan dari hasil pembagian tegangan maksimum dengan luas penampang melintang. Luas penampang melintang didapatkan dari hasil perkalian panjang awal sampel dengan ketebalan awal sampel. Uji kekuatan tarik dilakukan pada tiga sampel film yang kemudian dihitung rata-ratanya.

\section{Pembuatan Film Plastik Biodegradable}

\section{Isolasi Pati Ubi Kayu}

Penelitian tentang pembuatan film plastik ini diawali dengan pembuatan pati dari ubi kayu. Tahapan dalam membuat pati ubi kayu yaitu pencucian, pengupasan, dan disintegrasi, penirisan, penghalusan, pengeringan, dan penyaringan/pemfilteran. Dalam proses pembuatan film plastik, terlebih dahulu dibuat bahan baku yaitu pati ubi kayu yang kering. Proses pembuatan pati ubi kayu diawali dengan mencuci ubi kayu, kemudian ubi kayu tersebut dikupas sehingga dihasilkan ubi kayu bersih dan putih. Setelah didapat ubi kayu yang bersih dan putih, ubi kayu dipisahkan dari serat yang ada ditengah umbi. Ubi kayu kemudian dihaluskan dengan cara diparut. Hasil parutan ubi kayu kemudian dicampurkan dengan air dan diaduk selama 30 menit, setelah itu campuran parutan ubi kayu dan air disaring dengan kain bersih. Hasil penyaringan tadi kemudian diendapkan selama 4 jam untuk mendapatkan endapan pati. Setelah 4 jam endapan dipisahkan dari air. Endapan yang didapat kemudian dikeringkan di bawah sinar matahari sampai kering. Pati yang kering kemudian digerus menggunakan mortal dan diayak dengan menggunakan ayakan 200 mesh.

Tepung pati ubi kayu yang dihasilkan mempunyai beberapa karakteristik secara fisik. Tepung pati berbentuk serbuk, berwarna putih dan masih memiliki aroma ubi kayu. Sebanyak $2 \mathrm{~kg}$ ubi kayu yang dibuat menjadi tepung, dihasilkan 300 gram tepung pati. Artinya rendemen pati yang dihasilkan sebesar $15 \%$ per berat ubi kayu yang digunakan. Tepung pati yang dihasilkan kemudian digunakan untuk proses pembuatan plastik. 


\section{Struktur Morfologi Film Plastik Biodegradable}

Dari hasil penelitian yang dilakukan, telah didapatkan film plastik biodegradable yaitu dengan mengeringkan lelehan formula pati ubi kayu, aquades, dan pemlastis gliserol. Penelitian ini menggunakan 3 variasi gliserol, yaitu menggunakan larutan gliserol 85\% sebanyak $2 \mathrm{ml}, 3 \mathrm{ml}$ dan $4 \mathrm{ml}$ yang dicampurkan pada $50 \mathrm{ml}$ larutan pati ubi kayu. Gliserol sebagai bahan tambahan yang dicampurkan pada saat pembuatan film plastik karena tanpa pemlastis film plastik yang dihasilkan bersifat getas dan rapuh. Adapun pemlastis yang digunakan adalah gliserol, karena gliserol merupakan bahan yang murah, sumbernya mudah diperoleh, dapat diperbaharui dan juga akrab dengan lingkungan karena mudah terdegradasi dalam alam. Fungsi gliserol pada penelitian ini adalah sebagai pemplastis yang berfungsi untuk mendapatkan sifat mekanis yang lunak, ulet dan kuat dari film plastik yang telah dibuat.

Metode yang digunakan dalam pembuatan film plastik adalah metode pencetakan larutan. Campuran adonan film plastik dapat dilihat pada tabel. 2

Tabel.2 Campuran Adonan Film Plastik

\begin{tabular}{cccccc}
\hline \multirow{2}{*}{$\begin{array}{c}\text { Kode } \\
\text { Sampel }\end{array}$} & $\begin{array}{c}\text { Pati } \\
\text { (g) }\end{array}$ & $\begin{array}{c}\text { Aquades } \\
\text { (ml) }\end{array}$ & $\begin{array}{c}\text { Gliserol } \\
(\mathrm{ml})\end{array}$ & $\begin{array}{c}\text { Asam asetat } \\
\mathbf{1 \%}(\mathrm{ml})\end{array}$ & $\begin{array}{c}\text { NaOh 1\% } \\
\text { (ml) }\end{array}$ \\
\hline A & 15 & 50 & 2 & 3 & 20 \\
\hline B & 15 & 50 & 3 & 4 & 39 \\
\hline C & 15 & 50 & 4 & 5 & 50 \\
\hline
\end{tabular}

Langkah yang dilakukan adalah dengan mencampurkan 15 gram pati ubi kayu kemudian dicampurkan dengan $50 \mathrm{ml}$ aquades dan $2 \mathrm{ml}$ gliserol juga $3 \mathrm{ml}$ asam asetat diaduk dengan magnetik stirerr selama 5 menit, kemudian tambahkan $\mathrm{NaOH} 1 \%$ sebanyak $0.1 \mathrm{ml}$ sampai netral. Larutan kemudian dipanaskan hingga berbentuk adonan yang kental dan kemudian dicetak pada cetakan stainless steel.

Adonan yang telah dicetak kemudian dioven dengan suhu $45^{\circ} \mathrm{C}$ selama 6 jam. Setelah kering, film plastik didinginkan pada suhu ruangan selama 6 jam kemudian diangkat dari cetakan Hasil film berupa lembaran berwarna putih transparan dan elastis (Gambar 5) yang kemudian diuji densitas (kerapatan), dan uji tarik untuk mengetahui standar dan kelayakannya. 


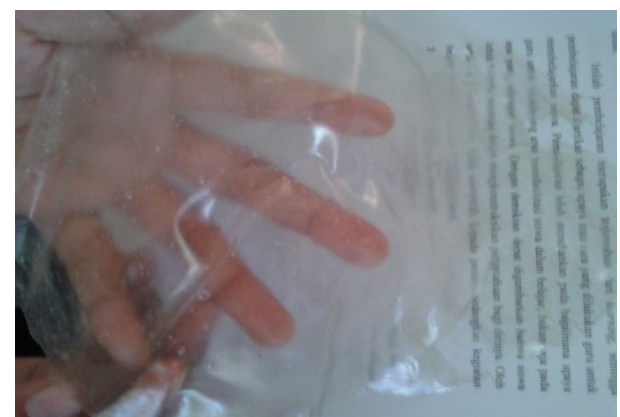

Gambar.4. Plastik Biodegradable

Sifat fisis dari plastik yang dihasilkan seperti tertera pada table 3 berikut:

Tabel 3. Sifat Fisis Plastik yang Dihasilkan

\begin{tabular}{|c|l|l|l|l|}
\hline \multirow{2}{*}{ No } & \multirow{2}{*}{ Sifat Fisik } & \multicolumn{3}{|c|}{ Hasil Pengamatan } \\
\cline { 3 - 5 } & & \multicolumn{2}{|c|}{$\mathbf{2}$} & \multicolumn{2}{|c|}{$\mathbf{3}$} \\
\cline { 3 - 5 } & Bentuk & $\begin{array}{l}\text { Lembaran } \\
\text { plastik } \\
\text { transparan }\end{array}$ & $\begin{array}{l}\text { Lembaran } \\
\text { plastik } \\
\text { transparan }\end{array}$ & $\begin{array}{l}\text { Lembaran plastik } \\
\text { transparan }\end{array}$ \\
\hline 2 & Warna & Putih transparan & Putih transparan & Putih transparan \\
\hline 3 & Tekstur & Kesat dan halus & Kesat dan halus & Kesat dan halus \\
\hline 4 & Liat / tidak & Kurang elastic & Elastis & Agak elastic \\
\hline
\end{tabular}

Karakterisasi struktur mikro permukaan film plastik dilakukan dengan menggunakan Scanning Electron Microscope (SEM). Sebelum dimasukkan ke dalam SEM, sampel film plastik dipotong kecil-kecil berukuran $1 \times 1 \mathrm{~cm}^{2}$ kemudian sampel yang sudah dipotong diletakkan di holder untuk proses coating (pelapisan sampel dengan emas agar sampel bersifat konduktif). Alat coating yang digunakan bernama Sputter Coater. Pada proses pelapisan/coating, sampel divakumkan selama 30 menit dengan tekanan $3 \mathrm{~Pa}$ dan intensitas arus listrik $18 \mathrm{~mA} / 75$ detik. Hasil karakterisasi struktur mikro film plastik dari pati ubi kayu dapat dilihat pada Gambar 4.3 yang menunjukkan struktur mikro permukaan film plastik dengan perbesaran 5000x.

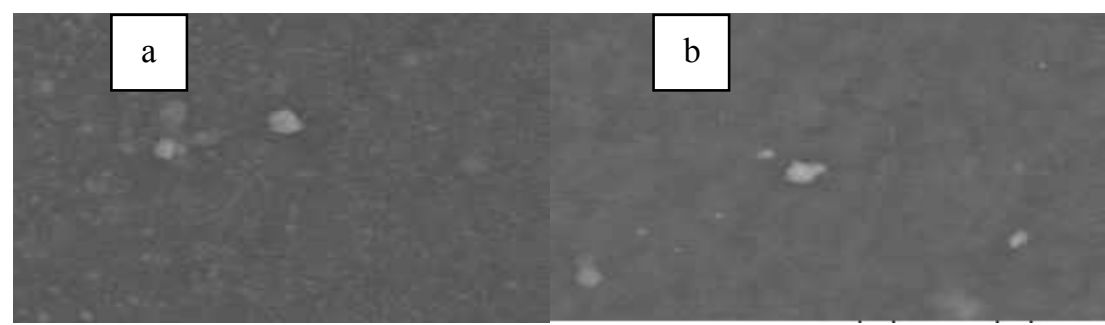

Gambar 4. (a) morfologi plastik biodegradable dengan variasi volume gliserol

$2 \mathrm{ml}$; (b) morfologi plastik biodegradable dengan variasi volume $3 \mathrm{ml}$ 


\section{Uji Densitas dan Uji Tarik}

Pengujian densitas dilakukan dengan mengukur ketinggian dan massa sampel yang telah dipotong dengan ukuran $20 \mathrm{~mm}$ x $10 \mathrm{~mm}$. Ketinggian diukur dengan menggunakan micrometer secrup, dengan pengkuran berulang sebanyak tiga kali pada lima tempat yang berbeda dengan hasil sebagai berikut: untuk film plastik dengan variasi volume $2 \mathrm{ml}: 0,23 \mathrm{~mm}, 1,17 \mathrm{~mm}, 1$, $33 \mathrm{~mm}, 1,35 \mathrm{~mm}$ dan 1, $35 \mathrm{~mm}$; untuk film plastik dengan variasi volume $3 \mathrm{ml}$ tingginya adalah $0,4 \mathrm{~mm}, 0,17 \mathrm{~mm}, 0,18 \mathrm{~mm}, 0,18 \mathrm{~mm}$ dan 0,16 $\mathrm{mm}$; dan untuk film plastik dengan variasi volume gliserol $4 \mathrm{ml}$ tingginya adalah 0,37 $\mathrm{mm}, 0,39 \mathrm{~mm}, 0,29 \mathrm{~mm}, 1,4 \mathrm{~mm}$ dan 0,28 mm. Massa sampel diukur dengan menggunakan neraca digital dengan masing-masing massa sampel adalah sebagai berikut: untuk film plastik dengan variasi volume gliserol $2 \mathrm{ml}$ massanya adalah $0,07 \mathrm{~g}, 0,13 \mathrm{~g}, 0,14 \mathrm{~g}, 0,11 \mathrm{~g}$ dan $0,13 \mathrm{~g}$; untuk film plastik dengan variasi volume gliserol $3 \mathrm{ml}$ massanya adalah $0,09 \mathrm{~g}, 0,05 \mathrm{~g}, 0,05 \mathrm{~g}$, $0,05 \mathrm{~g}$ dan $0,07 \mathrm{~g}$; dan untuk film plastik dengan variasi volume gliserol $4 \mathrm{ml}$ massanya sebagai berikut: 0,12 g, 0,14 g, 0,08 g, 0,16 g, 0,1 g.

Berdasarkan hasil perhitungan diperoleh nilai densitas untuk masingmasing sampel sebagai berikut: untuk film plastik dengan variasi volume gliserol $2 \mathrm{ml}$ adalah $0,0018 \mathrm{~g} / \mathrm{mm}^{3}, 0,0006 \mathrm{~g} / \mathrm{mm}^{3}, 0,0005 \mathrm{~g} / \mathrm{mm}^{3}, 0,0004$ $\mathrm{g} / \mathrm{mm}^{3}$ dan $0,0005 \mathrm{~g} / \mathrm{mm}^{3}$; . untuk film plastik dengan variasi volume gliserol $3 \mathrm{ml}$ adalah $0,0011 \mathrm{~g} / \mathrm{mm}^{3}, 0,0015 \mathrm{~g} / \mathrm{mm}^{3}, 0,0014 \mathrm{~g} / \mathrm{mm}^{3}, 0.0015 \mathrm{~g} / \mathrm{mm}^{3}$ dan $0,0022 \mathrm{~g} / \mathrm{mm}^{3}$; untuk film plastik dengan variasi volume gliserol $4 \mathrm{ml}$ adalah $0.0016 \mathrm{~g} / \mathrm{mm}^{3}, 0,0018 \mathrm{~g} / \mathrm{mm}^{3}, 0,0014 \mathrm{~g} / \mathrm{mm}^{3}, 0,0006 \mathrm{~g} / \mathrm{mm}^{3}$ dan 0,0018 $\mathrm{g} / \mathrm{mm}^{3}$. Dengan rata-rata nilai densitas dapat dilihat pada tabel 4 .

Tabel 4. Rata-rata Nilai Densitas

\begin{tabular}{cccc}
\hline \multirow{2}{*}{ Sampel } & \multicolumn{3}{c}{ Densitas $\left(\mathrm{g} / \mathrm{mm}^{3}\right)$} \\
\cline { 2 - 4 } & $\begin{array}{c}\text { Variasi Volume } \\
\text { Gliserol 2 ml }\end{array}$ & $\begin{array}{c}\text { Variasi Volume } \\
\text { Gliserol 3 ml }\end{array}$ & $\begin{array}{c}\text { Variasi Volume } \\
\text { Gliserol 4 ml }\end{array}$ \\
\hline 1 & 0,0018 & 0,0011 & 0,0016 \\
\hline 2 & 0,0006 & 0,0015 & 0,0018 \\
\hline 3 & 0,0005 & 0,0014 & 0,0014 \\
\hline 4 & 0,0004 & 0,0015 & 0,0006 \\
\hline 5 & 0,0005 & 0,0022 & 0,0018 \\
\hline Rata-Rata & 0,0008 & 0,0015 & 0,0014 \\
\hline
\end{tabular}

Dari hasil pengujian menggunakan tensile tester nilai $\mathrm{F}_{\max }$ untuk film plastik dengan variasi Volume $2 \mathrm{ml}, 3 \mathrm{ml}$ dan $4 \mathrm{ml}$ adalah 4,84 N, 55,47 $\mathrm{N}$ dan $31,9 \mathrm{~N}$. Dengan panjang masing-masing sampel $1,475 \mathrm{~mm}, 1,47 \mathrm{~mm}$ dan 1,445 $\mathrm{mm}$. Untuk tebal sampel pengukuran dilakukan di tiga tempat yang berbeda, 
untuk film plastik dengan variasi volume $2 \mathrm{ml}$ adalah 0,189 mm. 0,351 $\mathrm{mm} \mathrm{dn}$ $0,328 \mathrm{~mm}$; untuk film plastik dengan variasi volume $3 \mathrm{ml}$ adalah 0,388 $\mathrm{mm}$, 0,476 $\mathrm{mm}$ dan $0.194 \mathrm{~mm}$; dan untuk film plastik dengan variasi volume $4 \mathrm{ml}$ tebalnya adalah $0,472 \mathrm{~mm}, 0,477 \mathrm{~mm}$ dan $0,517 \mathrm{~mm}$.

Berdasarkan hasil perhitungan diperoleh nilai kuat tarik sebagai berikut: untuk film plastik dengan variasi volume $2 \mathrm{ml}$ adalah 0,174 Mpa, 0,093 Mpa dan 0,1 Mpa; selanjutnya untuk film plastik dengan variasi volume gliserol $3 \mathrm{ml}$ diperoleh nilai kuat tarik 0,973 Mpa, 0,793 Mpa dan 1,945 Mpa; dan untuk film plastik dengan variasi volume $4 \mathrm{ml}$ nilai kuat tarik yang diperoleh adalah 0,468 Mpa, 0,463 Mpa dan 0,431 Mpa. Dengan rata-rata kuat tarik dan simpangan baku kuat tarik adalah sebagai berikut:

Tabel 5 Nilai Kuat Tarik Rata-rata

\begin{tabular}{cccc}
\hline \multirow{2}{*}{ Sampel } & \multicolumn{3}{c}{ Kuat Tarik (Mpa) } \\
\cline { 2 - 4 } & $\begin{array}{c}\text { Variasi Volume } \\
\text { Gliserol 2 ml }\end{array}$ & $\begin{array}{c}\text { Variasi Volume } \\
\text { Gliserol 3 ml }\end{array}$ & $\begin{array}{c}\text { Variasi Volume } \\
\text { Gliserol 4 ml }\end{array}$ \\
\hline 1 & 0,1736 & 0,9725 & 0,4677 \\
\hline 2 & 0,0935 & 0,7927 & 0,4628 \\
\hline 3 & 0,9725 & 1,9451 & 0,4312 \\
\hline Rata-rata & 0,4132 & 1,2368 & 0,4539 \\
\hline
\end{tabular}

Nilai simpangan baku untuk nilai kuat tarik film plastik biodegradable dengan variasi volume $2 \mathrm{ml}, 3 \mathrm{ml}$ dan $4 \mathrm{ml}$ adalah berturut-turut sebagai berikut: 0,4860 Mpa, 0,62 Mpa dan 0,0198 Mpa.

\section{Variasi Volume Gliserol terhadap Nilai Densitas}

Pengukuran Kerapatan Biodegradable Plastik Kerapatan merupakan sifat fisik suatu polimer. Kerapatan suatu bahan berpengaruh terhadap sifat mekanik bahan tersebut, semakin rapat suatu bahan maka semakin meningkatkan sifat mekaniknya, sehingga film plastik yang dihasilkan mempunyai kekuatan tarik yang baik. Kerapatan atau densitas ini dapat didefinisikan sebagai massa per satuan volume bahan.

Pengukuran nilai densitas pada plastik sangat penting, karena densitas dapat menunjukkan struktur plastik secara umum. Aplikasi dari hal tersebut yaitu dapat dilihat kemampuan plastik dalam melindungi produk dari beberapa zat seperti air, 02 dan C02. Birley, dkk., (1988) dalam Ummah (2013), mengemukakan bahwa plastik dengan kerapatan yang rendah menandakan bahwa plastik tersebut memiliki struktur yang terbuka, artinya mudah atau dapat ditembusi fluida seperti air, oksigen atau $\mathrm{CO}_{2}$. Jadi, nilai kerapatan plastik sangat penting dalam menentukan sifat-sifat plastik yang berhubungan dengan pemakaiannya. 
Berdasarkan hasil penelitian, nilai densitas dari film plastik yng dihasilkan adalah seperti yang tertera pada tabel 6 .

Tabel 6 Nilai densitas Film Llastik

\begin{tabular}{cc}
\hline Variasi volume gliserol $(\mathrm{ml})$ & Densitas $(\mathrm{g} / \mathrm{mm} 3)$ \\
\hline 2 & $0,0008 \pm 0.0005$ \\
\hline 3 & $0.0015 \pm 0.0004$ \\
\hline 4 & $0.0014 \pm 0.0006$ \\
\hline
\end{tabular}

Pada Tabel 6 dapat dilihat bahwa variasi volume gliserol mempengaruhi densitas film plastik biodegradable yang dihasilkan. Terlihat bahwa nilai densitas paling tinggi berada pada variasi volume gliserol $3 \mathrm{ml}$, yakni sebesar $0.0015 \mathrm{~g} / \mathrm{mm}^{3}$. Nilai densitas terendah pada variasi volume gliserol $2 \mathrm{~m}$ sebesar $0,0008 \mathrm{ml}$. Dan pada variasi volume gliserol $4 \mathrm{ml}$ nilai densitas sebesar $0.0014 \mathrm{~g} / \mathrm{mm}^{3}$.

Nilai densitas terendah pada variasi volume gliserol $2 \mathrm{ml}$, hal ini disebabkan karena jumlah gliserol yang terlalu sedikit dibanding dengan jumlah pati yang digunakan dalam pembuatan adonan plastik sehingga menghasilkan plastik bertekstur getas dan ringan. Hal ini juga didukung oleh simpangan baku dan hasil citra morfologi film plastik yang dihasilkan ketiga sampel. Simpangan baku pada nilai densitas dapat menunjukan keragaman ketebalan plastik yang dihasilkan, sedangkan citra morfologi film plastik menunjukan penyebaran pati dan gliserol pada film plastik yang dihasilkan. Pada variasi volume gliserol $2 \mathrm{ml}$ nilai simpangan bakunya adalah $\pm 0,0005$ $\mathrm{g} / \mathrm{mm}^{3}$ menunjukan perbedaan densitas titik-titik pada film plastik yang diambil sebagai sampel tidak terlalu berbeda jauh. Sedangkan berdasarkan struktur morfologinya pada gambar 4.2 (a) dapat dilihat adanya titik-titik putih yang menyebar dipermukaan plastik. Titik-titik putih tersebut menunjukan penyebaran gliserol dan pati yang tidak seimbang dimana jumlah pati lebih banyak dari gliserol.

Nilai densitas dari variasi gliserol $2 \mathrm{ml}$ ke $3 \mathrm{ml}$ nilai densitas naik dari $0,0008 \pm 0,0005 \mathrm{~g} / \mathrm{mm}^{3}$ menjadi $0.0015 \pm 0.0004 \mathrm{~g} / \mathrm{mm}^{3}$ Hal ini disebabkan karena pada variasi volume gliserol $3 \mathrm{ml}$ ada keseimbangan antara volume gliserol yang digunakan dengan jumlah massa pati yang digunakan dalam pembuatan. yang mengakibatkan gliserol tersebar merata di dalam adonan pembuatan plastik yang menghasilkan plastik yang liat dan elastis. Hal ini juga didukung oleh simpangan baku dan hasil citra morfologi film plastik yang dihasilkan ketiga sampel pada variasi volume gliserol $3 \mathrm{ml}$ nilai simpangan bakunya adalah $\pm 0,0004 \mathrm{~g} / \mathrm{mm}^{3}$ menunjukan perbedaan densitas titik-titik pada film plastik yang diambil sebagai sampel yang hampir tidak berbeda. Dan merupakan simpangan yang terkecil dibandingkan dengan sampel untuk variasi gliserol $2 \mathrm{ml}$ dan $4 \mathrm{ml}$. Sedangkan berdasarkan struktur morfologinya 
pada gambar 4.2 (b) dapat dilihat dengan semakin berkurangnya titik-titik putih yang menunjukan penumpukan gliserol dan pati yang tidak merata.

Sedangkan nilai densitas dari variasi gliserol $3 \mathrm{ml}$ ke $4 \mathrm{ml}$ nilai densitas mengalami penurunan dari $0,0015 \pm 0,0004 \mathrm{~g} / \mathrm{mm}^{3}$ menjadi $0,0014 \pm 0,0006$ $\mathrm{g} / \mathrm{mm}^{3}$ Hal ini disebabkan oleh penyebaran gliserol yang tidak seimbang dengan banyaknya pati, dimana gliserol lebih banyak sehingga terjadi penumpukan gliserol pada titik-titik tertentu pada plastik yang dihasilkan. Penumpukan gliserol menyebabkan plastik menjadi lebih mulus tetapi lebih tipis dari titik-titik lainya. Sedangkan titik-titik yang lainnya yang tidak terdapat penumpukan gliserol tidak mulus. Hal inilah yang menyebabkan tekstur plastik yang terbentuk memiliki keelatisan yang kurang baik karena pada bagian yang terjadi penumpukan gliserol menjadi terlalu liat atau elastis. Hal ini juga didukung oleh simpangan baku dan hasil citra morfologi film plastik yang dihasilkan ketiga sampel pada variasi volume gliserol $4 \mathrm{ml}$ nilai simpangan bakunya adalah $\pm 0,0006 \mathrm{~g} / \mathrm{mm}^{3}$ dimana nilai ini menunjukan perbedaan densitas titik-titik pada film plastik yang diambil sebagai sampel berbeda jauh jika dibandingakan dengan variasi $2 \mathrm{ml}$ dan $3 \mathrm{ml}$. Dengan membandingkan srtuktur morfologi dan simpangan baku untuk kedua sampel sebelumnya maka dapat diasumsikan bahwa keragaman ketebalan plastik pada variasi volume gliserol $4 \mathrm{ml}$ berbeda jauh.

Penyebaran gliserol yang tidak merata ini juga disebabkan karena proses pembuatan yang kurang didukung dengan alat yang baik, dimana dalam proses pengadukan dan pemanasan suhu hot plates yang tidak stabil yang menyebabkan waktu pengadukan yang tidak seragam, karena apabila terlalu lama pengadukan dan pemanasan adonan plastik akan hangus. Selain itu pada proses pencetakan yang dilakukan dengan cara manual dengan viskositas adonan yang tinggi yang menyebabkan pemerataan adonan dalam cetakan yang susah merata. Kedua hal ini menyebabkan struktur morfologi yang kurang baik dari ketiga variasi sampel.

Hasil yang didapatkan mendekati standar untuk LDPE. (Low Density Poly Ethylene) dengan nilai 0,91-0,94 kg/l atau 0,00091-0.00094 g/mm³. Kerapatan film plastik yang dihasilkan ini lebih baik dari hasil penelitian sebelumnya Harnist dan Darni (2012) tentang Penentuan Kondisi Optimum Konsentrasi Plasticizer pada Sintesa Plastik Biodegradable Berbahan Dasar Pati Sorgum.dengan nilai densitas $0,61 \mathrm{~g} / \mathrm{mm}^{3}$ dan $1,61 \mathrm{~kg} / \mathrm{l}$ untuk penelitian Ummah (2013) tentang Uji Ketahanan Biodegradable Plastic Berbasis Tepung Biji Durian (Durio Zibethinus Murr) terhadap Air dan Pengukuran Densitasnya. 


\section{Variasi Volume Gliserol terhadap Kuat Tarik}

Sifat mekanik film plastik dipengaruhi oleh besarnya jumlah kandungan komponen-komponen penyusun film yaitu pati dan gliserol. Gliserol sebagai plastisiser dapat memberikan sifat elastis pada plastik. Film berbahan pati saja bersifat lebih elastis serta memiliki kekuatan tarik dan persen elongasi yang rendah (Darni dkk, 2008). Faktor penting yang mempengaruhi sifat mekanik bahan bioplastik adalah afinitas antara komponen penyusunnya.

Afinitas merupakan suatu fenomena atom atau molekul tertentu memiliki kecenderungan untuk bersatu dan berikatan. Semakin meningkat afinitas, semakin banyak terjadi ikatan antar molekul. Kekuatan suatu bahan dipengaruhi oleh ikatan kimia penyusunnya. Ikatan kimia yang kuat bergantung pada jumlah ikatan molekul dan jenis ikatannya.ikatan yang kuat akan sulit diputus, sehingga untuk memutuskan ikatan akan diperlukan energi yang besar (Herti, 2010).

Nilai kuat tarik plastik biodegradable yang dihasilkan pada penelitian ini disajikan dalam grafik yang terdapat pada gambar 3 .

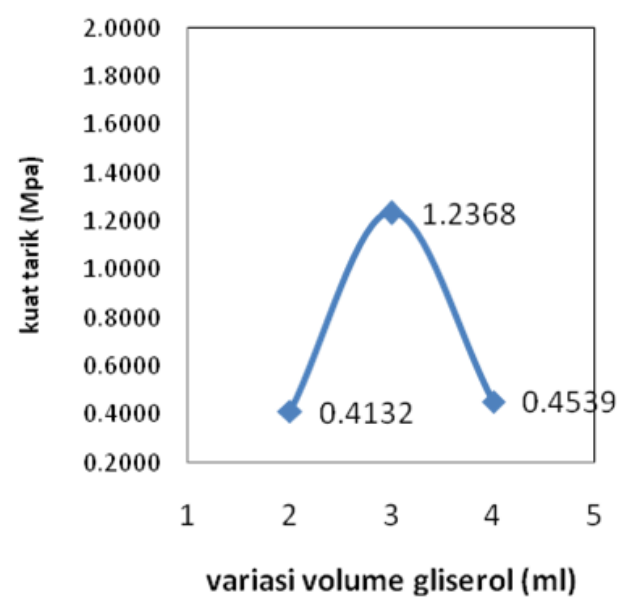

Gambar 3 Hubungan Variasi Volume dan Kuat Tarik Film Plastik

Berdasarkan data yang diperoleh, terlihat bahwa kekuatan tarik plastik pada variasi volume gliserol $2 \mathrm{ml}$ sebesar $0.0041 \mathrm{Mpa}$, pada variasi volume gliserol $3 \mathrm{ml}$ sebesar 0,0124 Mpa dan pada variasi volume gliserol $4 \mathrm{ml}$ sebesar $0.0045 \mathrm{Mpa}$.

Terlihat bahwa nilai kuat tarik terendah terdapat pada plastik dengan variasi volume gliserol $2 \mathrm{ml}$. Hal ini disebabkan oleh pada variasi gliserol $2 \mathrm{ml}$ ikatan antar polisakarida lebih banyak dari ikatan polisakarida yang diputus oleh gliserol sehingga plastik yang dihasilkan lebih kaku dibandingkan dengan pada variasi volume $3 \mathrm{ml}$ dan $4 \mathrm{ml}$. Selain itu juga penyebaran gliserol yang tidak merata dan lebih sedikit dengan banyaknya pati yang digunakan. Nilai kuat tarik terendah untuk film plastik dengan variasi volume gliserol 2 
ml juga didukung oleh nilai densitas yang juga terkecil dari kedua sampel lainnya. Morfologi permukaan untuk variasi ini dapat dilihat dari (Gambar 4.2 (b)) dimana penyebaran gliserol yang tidak merata dan tidak seimbangnya gliserol dengan pati sehingga menghasilkan plastik yang tingkat elastisitasnya kurang.

Dari variasi volume gliserol $2 \mathrm{ml}$ ke $3 \mathrm{ml}$ kuat tarik meningkat dari 0,0041 Mpa menjadi 0,0124 Mpa. Kenaikan yang tajam ini disebabkan karena ikatan polisakarida seimbang dengan polisakarida yang diputuskan oleh gliserol dan juga penyebaran gliserol dan pati yang merata. Penyebaran yang merata ini menghasilkan ikatan yang kuat sehingga nilai kuat tarik dari plastik menjadi lebih baik. Nilai kuat tarik didukung dengan nilai densitas, film plastik dengan variasi volume gliserol $3 \mathrm{ml}$ memiliki nilai densitas yang lebih tinggi dari sampel-sampel lainnya. Nilai kuat tarik juga didukung dengan hasil uji morfologi plastik dimana pada film plastik dengan variasi volume gliserol $3 \mathrm{ml}$ (Gambar 4.2 (b)) terlihat film plastik yang halus dan penyebaran gliserol yang merata dan seimbang dengan penyebaran pati yang menyebabkan elastisitas film plastik yang baik

Sedangkan ketika variasi volume gliserol dinaikan dari $3 \mathrm{ml}$ ke $4 \mathrm{ml}$ kuat tarik mengalami penurunan. Penurunan ini berhubungan dengan adanya ruang kosong yang terjadi karena ikatan antar polisakarida diputus oleh gliserol.. Hal ini menyebabkan ikatan antar molekul dalam film plastik tersebut semakin melemah. Kenaikan penambahan konsentrasi plasticizer yang menyebabkan semakin berkurangnya nilai kuat tarik, sesuai dengan semakin berkurangnya interaksi intermolekular (Bourtoom, 2008). Penurunan hasil kuat tarik juga disebabkan pula oleh distribusi tidak sempurna dari masing-masing komponen penyusun film plastik. Meningkatnya jumlah plasticizer yang digunakan menghasilkan mobilitas yang lebih besar terhadap makromolekul pati. Hal ini mengakibatkan kuat tarik bioplastik menurun (Tudorachi, dkk., 2000). Selain itu Interaksi ini berkurang karena adanya gliserol yang menyisip dan menghilangkan ikatan hidrogen di antara molekul polisakarida.

Hasil yang didapatkan jauh lebih kecil dari hasil kuat tarik pada penelitian Romadloniyah (2012) tentang pembuatan dan karakterisasi plastik biodegradable dari onggok singkong dengan plasticizer sorbitol dengan kuat tarik sebesar 126,87 Mpa. Anggarini, (2013) tentang aplikasi plasticizer gliserol pada pembuatan plastik biodegradable dari biji nangka yaitu dengan kuat tarik 24,7-302 Mpa dan Coniwanti yang meneliti tentang pembuatan film plastik biodegredabel dari pati jagung dengan penambahan kitosan dan pemplastis gliserol dengan nilai kuat tarik 3,92 Mpa. 


\section{Penutup}

\section{Simpulan}

Berdasarkan hasil penelitian ini dapat disimpulan bahwa

1. Hasil pengukuran densitas plastik biodegradable dengan variasi volume gliserol $2 \mathrm{ml}, 3 \mathrm{ml}$ dan $4 \mathrm{ml}$ berturut-turut adalah sebagai berikut 0.0009 $\mathrm{g} / \mathrm{mm}^{3}, 0.0015 \mathrm{~g} / \mathrm{mm}^{3}$ dan $0.0014 \mathrm{~g} / \mathrm{mm}^{3}$. Nilai densitas tertinggi adalah sampel dengan variasi volume gliserol $3 \mathrm{ml}$ sebesar $0,0015 \mathrm{~g} / \mathrm{mm}^{3}$, sedangkan nilai densitas terendah adalah sampel dengan variasi volume gliserol $2 \mathrm{ml}$ sebesar $0,0009 \mathrm{~g} / \mathrm{mm}^{3}$.

2. Kekuatan tarik plastik pada $2 \mathrm{ml}$ sebesar $0.0041 \mathrm{Mpa}$, pada variasi volume gliserol $3 \mathrm{ml}$ sebesar 0,0124 Mpa dan pada variasi volume gliserol $4 \mathrm{ml}$ sebesar $0.0045 \mathrm{Mpa}$. Nilai kuat tarik tertinggi adalah sampel dengan variasi volume gliserol $3 \mathrm{ml}$ sebesar 0,0124 Mpa dan nilai kuat tarik terendah adalah sampel dengan variasi volume gliserol $2 \mathrm{ml}$ sebesar 0,0041 Mpa.

Saran

Eksplorasi gliserol terhadap sifat fisis plastik berbahan dasar pati ubi kayu menarik untuk dikembangkan terlebih untuk menghasilkan bahan kaca film yang kuat dan ramah lingkungan.

\section{Daftar Pustaka}

Darni, Yuli, A. Chici, and S. D. Ismiyati. "Sintesa Bioplastik Dari Pati Pisang Dan Gelatin Dengan Plasticizer Gliserol." In Dalam Seminar Nasional Sains Dan Teknologi II, 2008.

Fessenden, Ralph J., and Joan S. Fessenden. Organic Chemistry. 6 edition. Place of publication not identified: Cengage Learning, 1998.

Firdaus, Feris, and Chairil Anwar. "Potensi Limbah Padat-Cair Industri Tepung Tapioka Sebagai Bahan Baku Film Plastik Biodegradabel." Jurnal Logika 1, no. 2 (2004).

Julianti, Elisa, and Mimi Nurminah. Teknologi Pengemasan: Buku Ajar. Medan: Fakultas Pertanian Universitas Sumatera Utara, 2006.

Qushayyi, Vemy Suryo. “Desain Teknologi Pembuatan Plastik Biodegradable Dari Pati Sagu Dengan Pemanfaatan Fermentasi Asam Laktat (Kajian Penambahan Kitosan Dan Gelatin)." Sarjana, Universitas Brawijaya, 2014. http://repository.ub.ac.id/149882/.

Siswono. Jaringan Informasi Pangan Dan Gizi. Vol. XIV. Jakarta: Ditjen Bina Gizi Masyarakat, 2008.

Syarief, Rizal, Sassya Santausa, and S. T. Isyana. "Teknologi Pengemasan Pangan." Laboratorium Rekayasa Proses Pangan, PAU Pangan Dan Gizi, IPB, 1989.

Taylor, Vedder. Edible Film. London: CRC Press, 2008.

Wahyu, Maulana Karnawidjaja. "Pemanfaatan Pati Singkong Sebagai Bahan Baku Edible Film." Beswan Djarum. Fakultas Teknologi Industri Pertanian. Universitas Padjadjaran. Bandung, 2009. 